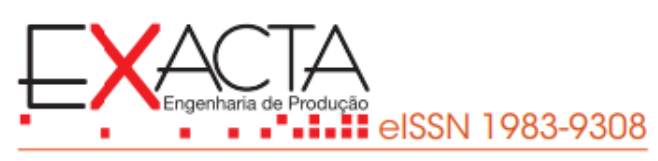

\title{
IMPLEMENTATION OF REGULATORY STANDARDS FOR TOBACCO-BRAZIL PRESSES
}

\author{
IMPLEMENTAÇÃO DE PADRÕES REGULAMENTARES PARA PRENSAS TABACO- \\ BRASIL
}

Versão do autor aceita publicada online: $18 \mathrm{dez} .2019$

Publicado online: 12 maio 2021

\section{Como citar esse artigo - American Psychological Association (APA):}

Nara, E. O. B., Benitez, G. B., Silva, A. L. E., Hernandes, F., Kothe, J. V., Baierle, I. C., Schaefer, J. L., Vinha, F., Ellert, B., Schreiber, J. N. C., \& Furtado, J. C. (2021, abr./jun.). Implementation of regulatory standards for tobacco-Brazil presses. Exacta, 19(2), 374-392. https://doi.org/10.5585/exactaep.2021.12396.

Submeta seu artigo para este periódico $\Re$

Dados Crossmark 


\title{
IMPLEMENTATION OF REGULATORY STANDARDS FOR TOBACCO-BRAZIL PRESSES
}

\author{
IMPLEMENTAÇÃO DE PADRÕES REGULAMENTARES PARA PRENSAS TABACO-BRASIL
}

(DElpidio Oscar Benitez Nara ${ }^{1}$

DGuilherme Brittes Benitez ${ }^{2}$

(DAndré Luiz Emmel Silva ${ }^{3}$

Fabio Hernandes ${ }^{4}$

(D) Jã̃o Victor Kothe ${ }^{5}$

()|smael Cristofer Baierle ${ }^{6}$

(ㄱ) Jones Luís Schaefer ${ }^{7}$

Francele Vinha ${ }^{8}$

(1)Bruno Ellert ${ }^{9}$

(D)Jacques N. C. Schreiber ${ }^{10}$

(D) João Carlos Furtado ${ }^{11}$

\section{${ }^{1}$ Doutor}

Universidade Federal de Santa Maria - UFSM.

elpidio.nara@outlook.com

2 Doutor

Universidade Federal do Rio Grande do Sul-UFRGS

guilherme.benitez@hotmail.com

${ }^{3}$ Mestre

Universidade de Santa Cruz Do Sul-UNISC andresilva@unisc.br

4 Engenheiro de produção

Universidade de Santa Cruz Do Sul-UNISC

fabio_hernandes2000@yahoo.com.br

5 Engenheiro mecânico

Universidade de Santa Cruz Do Sul-UNISC

joaokothe@mx2.unisc.br

${ }^{6}$ Doutor

Universidade Federal de Santa Maria (UFSM)

ismaelbaierle@hotmail.com

7 Mestre

Universidade Federal de Santa Maria (UFSM)

engjlschaefer@yahoo.com.br

8 Engenharia de produção

Universidade de Santa Cruz Do Sul-UNISC

francielevina@hotmail.com

${ }^{9}$ Engenharia civil

Universidade de Santa Cruz Do Sul-UNISC

brunoellert@mx2.unisc.br

10 Doutor

Universidade de Santa Cruz Do Sul-UNISC

jacques@unisc.br

11 Doutor

Universidade de Santa Cruz Do Sul-UNISC

jcarlosf@unisc.br

Recebido em: 26 fev. 2019

Aprovado em: 18 dez. 2019
Abstract: The main legislation applied to machines in Brazil is the Regulatory Standard 12 (NR-12) dealing with the Workplace Safety in machinery and equipment which was approved by Ordinance No. 3241 in June 8th, 1978 by the Ministry of Labour. The NR-12 defines technical references, fundamental principles and protective measures to ensure the health and physical integrity of workers. In this context, the goal of this work is to suggest security measures in a pneumatic press of tobacco according to Regulation Standard No. 12, as well as ensure the workers safety. We utilized a risk evaluation method known as HRN (Hazard Rating Number) applied to offer greater precision in risk checks on machines. Our results indicate the security measures that should be adopted for the implementation of the NR-12 in tobacco presses.

Keywords: Safety in machinery and equipment. Brazilian regulatory norms. Tobacco presses. Protective measures. Risk machinery.

Resumo: A principal legislação aplicada às máquinas no Brasil é a Norma Regulamentadora 12 (NR-12) que trata da Segurança do Trabalho em máquinas e equipamentos que foi aprovada pela Portaria no 3.241 , de 8 de junho de 1978, do Ministério do Trabalho e Emprego. A NR-12 define referências técnicas, princípios fundamentais e medidas de proteção para garantir a saúde e integridade física dos trabalhadores. Nesse contexto, o objetivo deste trabalho é sugerir medidas de segurança em uma prensa pneumática de fumo de acordo com a Norma Regulamentadora no 12, bem como garantir a segurança dos trabalhadores. Utilizamos um método de avaliação de risco conhecido como HRN (Hazard Rating Number) aplicado para oferecer maior precisão nas verificações de risco nas máquinas. Nossos resultados indicam as medidas de segurança que devem ser adotadas para a implantação da NR-12 nas prensas de tabaco.

Palavras-chave: Segurança em máquinas e equipamentos. Normas regulatórias brasileiras. Prensas de tabaco. Medidas protetoras. Máquinas de risco. 


\section{Introduction}

The competition increasement between companies, which face several changes rapidly make the search for new technologies become more prevalent. In this scenario, there is no more space for improvisations, been needed competence, creativity, flexibility, speed, culture change and teamwork as key requirements for companies and organizations to remain their competitiveness. These requirements poses challenges with levels of uncertainty and complexity largest to be solved in order to allow interdependencies and reinforcements for manufacturing system more responsive (Riis et al., 2007). The nowadays management must be supported by a future vision and governed by management processes where customer satisfaction is a result of the intrinsic quality of products and services and the overall quality of the production processes (Pinto \& Xavier, 2001).

Concerning to work safety and the environment, legal requirements must be considered for the proper handling of equipment, aiming at the integration of man- machine-environment for the companies to provide products in accordance with existing laws. Prevention measures adopted in companies should not only be implemented willing to attend laws, but rather to focus on the safety and health of their workers (Vasconcelos et al., 2015). To the physical integrity of its operators. "[...] the work safety should comprise a set of recognition activities, evaluation and control of accidents and risks at work and occupational diseases" (Pacheco, 1995).

The Statistical Yearbook of the International Labour Organization (ILO) 2010 reports that Brazil is the 5th in the world rank in workplace accidents, losing to China, India, Indonesia and the United States (Anuário Brasileiro, 2010). These data refer to accidents in countries with more than 50 thousand workers. About 270 million workers are victim's of accidents at work every year (Savi, 2012). The increase in these occurrences happens in a period which alternatives are being proposed in order to improve the safety and health of working environments referring about legislation (Shang, 2011). It is the manager's responsibility to encourage and support the safety, establishing a culture within the company, managing safety programs, inspections of equipment and reviewing the employees' performance.

In the Brazilian context, two of the most problematic occupational health issues are related to accidents and deaths at work (Prochnow et al. 2012; Cordeiro et al, 2017). According to Filho and Ramos (2015), occupational work is a problem for different departments such as govern, entrepreneur and worker who have great interest in manage it.

Brazil ever had a historic of lots of occupational accidents, for instance, in 1994, the country had 4.66 deaths per 1000 accidents, being 1.51 above the general median (Machado and Gomes, 1994). According to Cordeiro (2017) who utilizeddates from the Ministry of Social Security of Brazil, in 2013 
was recorded the occurrence of 702,685 occupational accidents, and in 2016 the Social Security data recorded that Brazil had 578,935 occupational accidents.

Occupational accidents entail in economic and social costs, especially in procedures in health care facilities (Ferreira, 2017); and costs to the payment of social security benefits (Ciesielski, 2013). The costs per year with accident and work-related is around R\$ 71 billion, this value represent $9 \%$ of the salary bill of the country (Malta, 2013). Usually the work accidents involving machines are caused by lack of investments in Nr-12 (Ciesielski, 2013). Therefore, this article aims to contribute to the NR 12 risk assessment analysis and shows its relevance in many aspects of different areas.

The main legislation applied to machines in Brazil is the Regulatory Norm \# 12 (NR-12) entitled "Safety at work in machinery and equipment" approved by Order No. 3241 in June 8th, 1978 in the Ministry of Labour and updated by Ordinance No. 293, December 8th, 2011 in the Ministry of Labour. The NR-12 defines technical references, primal principles and protective measures to ensure the health and physical integrity of workers, setting the minimum requirements for the prevention of accidents and occupational diseases in the phases of design and use of machinery, and equipment of all types, also concerning the manufacture, importation, marketing, and other aspects. It also considers protective measures as: collective protective measures, administrative measures or labor organization and personal protection measures.

Most countries use security requirements necessary to ensure that machinery without risks to their operators are imposing strict security (Caputo et al., 2013). Moreover, accidents in a general way result in costs due to downtime of the machines, and personal injury to employees been necessary toindustries strengthen workplace safety (Ajimotokan, 2012).

The NR-12 also considers other forms of accident prevention such as the workers training and preparation and elaboration of a security manual that should includes data on safety related since the assembly / installation of the machine until its junking. According to NR-12, 12:54 in its item, "[...] the protections, devices and systems must integrate machines and equipment, and cannot be considered optional items for any purpose" (Ministério do Trabalho e Emprego - MTE, 2011).

The present work was performed in a manufacturing company of pneumatic presses for Tobacco. A pneumatic press serves to compact the tobacco which consists in boxes whose dimensions vary from client to client. This press is used when it is not necessary much effort to compress the volume of tobacco within the boxes. A pneumatic press consists of pneumatic cylinders, which are responsible for the force applied to the hammer pressing on the product and charger, consisting of a hood, which directs the product inside the box, as, can be seen in Figure I. 


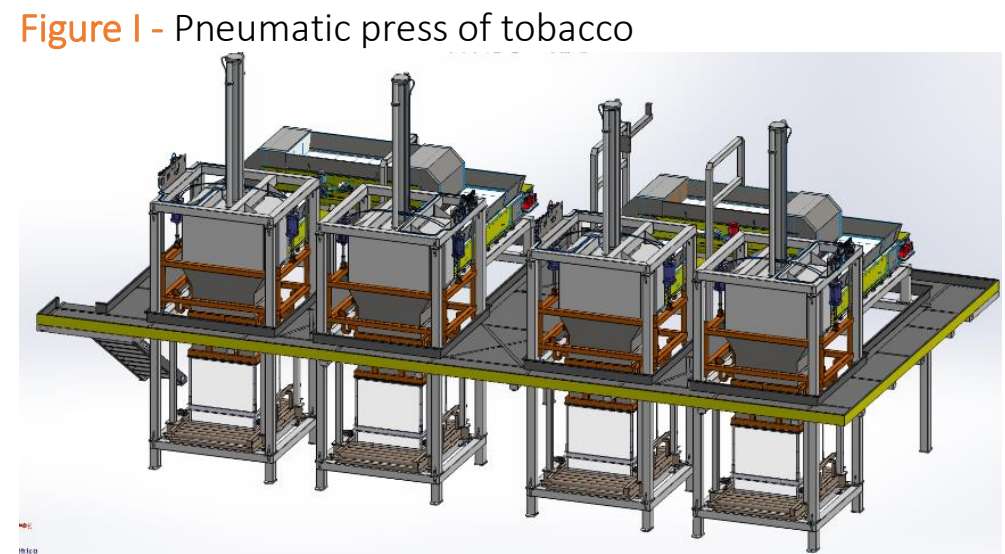

Source: elaborated by the authors, 2011.

This type of machine has great potential risks of accidents during its operation and must have security and protection systems and to prevent accidents. The work security is determined by specific laws focused at reducing workplace accidents, occupational diseases and to protect the integrity of employees. These laws aim to make the machines safer and prevent possible accidents.

The company also provides tobacco pneumatic press along with security systems; however, these are not adjusted with the standard norms required by law. They just rely on what is requested by their clients or their experience in other fabrications. Therefore, this study aims to suggest security measures for tobacco pneumatic presses using the Regulatory Norm No. 12 (approved by the Ministry of Labour), as well as ensure the safety of operators who work in them. This work is structured in five sections, beginning in the Introduction, followed by the Theoretical background, the Methodology, the Results and Discussions and finishing with Conclusions.

\section{Theoretical background}

\subsection{Work security}

The work security is becoming more popular due to its importance within companies. (Drakopoulos et al., 2012). This importance occurs by the fact of economic losses and social injuries related to work are quite troublesome. Additionally, most of companies work in a risky environment, especially the manufacturing ones, and do not realize the damage they may suffer (Fuller \& Vassie, 2001). This could be caused by the lack of motivation of workers who realized they are facing hazard environments in their work (Salaheldin \& Zain, 2007). Chan \& Chan, 2011 point out that accidents usually occur by oversights of the operator or by the poor design of the working environment. Work security can be termed as the set of measures taken to reduce workplace accidents and occupational diseases and also as protective measures to the integrity of employees. The Workplace Safety is determined by norms and specific laws (Areaseg, 2012). 
The need to reduce the risk of accidents could be seen as one of the main goals of a company, but needs more attention, considering the risks that a machine can provide for the operator (Ruz et al., 2012). Safety at work is highlighted in several standards, being broad number of situations that the operator is willing to deal with the machine. Cordero et al. (2009) state that the law should be stricter to ensure that companies comply with current legislation.The work safety legislation in Brazil is composed of regulatory norms, complementary laws, ordinances, regulations and decrees as well as international conventions of the ILO (International Labour Organization). As stated in Law No. 8213 in July 24th, 1991, which provides benefits plans for social security, the article 19 describes work accident as what happens through the course of work in the service of the company, causing body injuries or functional disorders that could cause death or permanently or temporarily loss or reduced work ability.

These standards address the requirements in steps that a machine must have to be considered safe for the operator, and evaluate each of the possible risks that it could offer (Cordero et al., 2009; Raouf, 2004). The primary purpose of a business is to have good productivity but companies should be concerned about the safety of their workers, and security on equipment due to accidents or nearaccidents interrupt the production process, causing disorders for workers and quality deterioration.

The occurrence of accidents involves immediate social harm. Firstly, the commitment of the health and physical integrity of the worker. Secondly, loss to their dependents who may eventually lose the support base family. Lastly, the costs that occur in social areas, especially in Health and Social Security (Cechin \& Fernandes, 2002).

The accidents are much debated in events on worker health and safety, according to the involvement in terms of sequels, and suffering of victims and their families, and the social and economic costs (Junior, 2009). To ensure that machinery and equipment are safer to the workers, the managers should have an attention to the characteristics of the place where this equipment is allocated and aspects such as temperature, humidity and dust, as well as the skill of the operator and his operating profile (Behzad et al., 2007). The adjustments in the machinery and equipment to the norms are fundamental in combating the numerous accidents that have high burden the society, and their reduction is desirable for everyone: employers, workers and government (Corrëa, 2012). On the literature some authors published articles about this matter in Brazil, as Veiga et al. (2017) who researched focused in Brazilian Amazon; Veiga (2017) researched accidents with Power tillers in Santa Catarina state; and Macedo et al. (2015) published an article characterizing accidents in farm machinery in Rio Grande do Sul state, all localized in Brazil. 


\subsection{Norms and legislation for safety in machinery}

The Brazilian Association of Technical Norms - ABNT has a literature about specific norms for machine safety. The NBR is an acronym that represents the Brazilian Norm, which was approved by ABNT. The NR stands for Regulatory Norm, established by the Ministry of Labour and Employment (MTE/Brazil), with mandatory feature.

There are thirty-five norms that deal with issues relating to occupational health and safety, and are mandatory compliance for all private and public companies, and public administration bodies directly and indirectly, as well as bodies of the Legislative and Judicial branches, which have employees under the Consolidated Labor Laws - CLT/Brazil. Their failure to comply may result in the application of penalty to the employer as required by law.

\subsection{NR-12 - Work safety in machinery and equipment}

The Regulatory Norm No. 12, entitled Safety at work in machinery and equipment, emphasizes the technique references, principles, protection measures, establishing thresholds for prevention of accidents and occupational diseases. This norm is legally assisted at the level of ordinary and specifically legislation in articles 184 to 186 of the Consolidation of Labor Laws - CLT, approved by Law No. 6514 in December 22, 1977, as quoted below:

Article 184 - Machinery and equipment shall be provided with starting and stopping devices and others that may be necessary for the prevention of occupational accidents, especially as the risk of accidental activation.

$\S$ Single - It is prohibited to manufacture, import, sale, lease and use of machinery and equipment that do not meet the provisions of this article.

Article 185 - Repairs, cleaning and adjustments can only be executed with the machines stopped, unless the motion is essential for completing the adjustment.

Article 186 - The Ministry of Labor will establish additional rules on protection and safety measures in the operation of machinery and equipment, especially the protection of moving parts, distance between them, means of access to machinery and large equipment, use of tools, its adequacy and security measures required when motorized or electric (MTE, 2011).

With respect to security systems, all the danger zones of machinery and equipment shall be protected by fixed barriers, mobile or safety devices interconnected to ensure the physical health of workers, as the item NR-12 12:38.

There are some requirements that must be met for the selection and installation of security systems, as evidenced in section 12:39 of the norm, such as: 
a) having security category as prior risk analysis provided in the current official technical norms;

b) being under the technical responsibility of a legally qualified professional;

c) possessing technical compliance with the control system that are integrated;

d) installation so that cannot be neutralized or circumvented;

e) remaining under automatic surveillance, or monitoring, according to safety category required, except for purely mechanical safety devices; and

f) stopping of dangerous movements and other risks when failures occur or abnormal labor situations (Ministério do Trabalho e Emprego - MTE, 2011).

Depending on the security category some machines must require rearm or manual reset after fault occurrence or any situation of abnormal operation. The NR-12, in item 12.41 considers protections, some elements that are used specifically to provide security through physical barriers such as:

a) fixed protection, which must be maintained in position permanently or through fasteners which only allow its removal or opening using specific tools; and

b) movable guard that can be opened without the use of tools, generally by mechanical elements connected to the machine frame or a fixed element close and must be associated with interlock switches (Ministério do Trabalho e Emprego - MTE, 2011).

All security systems of machinery must ensure the maintenance of safe state, due to the occurrence of fluctuations in energy level than those specified in the project, which must meet the cuts and restore electricity. When there is the need to access dangerous areas of machines with some frequency, should be used mobile security protections, however these protections must be installed according to NR-12 in item 12.44 , as follows:

a) protection should be associated with an interlock device when its opening not allow access to the danger zone before the elimination of risk; and

b) protection should be associated with an interlock switch with lock when its opening provides accessing to the danger zone before the risk elimination (Ministério do Trabalho e Emprego - MTE, 2011).

The interlocks associated with mobile security protections must ensure that the machine is turned off when any movable guard is opened, and the operation must be allowed only when all guards are closed. They also must ensure that the operation of the machine will not occur automatically with closing mobile protections. The same occurs with interlocks devices that lock and are installed in mobile 
protection of machinery and equipment. However, they should allow operation only when the guard is closed and locked, not allowing the opening of protection, keeping it closed and locked until the machine has eliminated all dangerous functions. Additionally, they must ensure that the operation of the machine will not occur automatically with the closing and locking of mobile guards. They should prevent, by means of fixed protections or mobile interlock device which does not have access to moving parts as well as the transmission of force, on all sides of the machine.

When the mobile components possess inertia it should be only allowed to use mobile protection through interlock switches with lock. According to item 12.49, NR-12, the protections must be designed and constructed to attend the following safety requirements:

a) carrying out their functions properly during the life of the machine or allow the replacement of decayed parts or damaged;

b) being constructed of materials resistant and adequate to containment and projection of parts, materials and particles;

c) fixation firm and guarantee of stability, and mechanical strength compatible with the efforts required;

d) not creating pinch points or grabbing with machine parts or other protection;

e) having no edges and sharp edges or other dangerous projections;

f) withstanding the environmental conditions of the place where they are installed;

g) preventing them from being circumvented;

h) providing hygiene and cleanliness;

i) preventing access to the danger zone;

j) having their interlock devices adequately protected against dirt, dust and corrosion, if necessary;

k) taking positive action, i.e. acting in a positive way; and

I) does not entail additional risks (Ministério do Trabalho e Emprego - MTE, 2011).

When security protections are produced by materials which leaked, screens, perforated plates, among others, it should be observed by safety distances. These distances shall be in accordance with the table of ABNT NBRNM-ISO 13852 - Safety of Machinery - Safety distances to prevent access to danger zones for upper limbs.

For security protections that are installed with a distance of machinery, for example, fences, and allow people who are within the danger zones, one should adopt additional measures of collective security to avoid activating the machine while these people are in danger zones. The NR-12 (MTE, 2011) 
cites "[...] the protections also used as a means of access required by the characteristics of the machine or equipment must attend the strength requirements and adequate security to both ends".

It should provide protections mirrors in the stairs whenever the possibility of foot or hand invasion in the danger zones. All that refers to "protections, devices or systems which must integrate machines and equipment, and cannot be considered optional items for any purpose" (MTE, 2011).

According to the risk in the machinery and equipment operation it can be required a project, a diagram or a schematic representation showing all security systems installed. This document must be written in Portuguese. For machinery and equipment already in operation, and according to the risk in the operation is responsibility of the owner to provide legal documentation, with proper Technical Responsibility Annotation - ART registered with the Regional Council of Engineering and Architecture CREA, proving that a qualified professional executed the project.

\section{Methodology}

Our method is characterized as an action research, where the researcher interacts in a participatory manner, with some back-end processing, resulting in an outcome consistent with the objectives established at the beginning of the work. The survey was developed in four stages: a) problem identification; b) data collection; c) verification of the need for change; and d) way definition through planning, and finally the evaluation, which can be implemented over structured actions. Data were collected between July to September 2012, with weekly interventions by company's engineers. We used the HRN (Hazard Rating Number) method to offer greater precision in risk checks on machines (Silva \& Souza, 2011). HRN is a quantitative method which numeric values are assigned. The probability of exposure $(\mathrm{PE})$ consists in verify the degree of exposure that a person could have in a danger zone. The frequency of exposure to hazard (FE) lists the frequency at which the person is exposed to danger. The probability of maximum loss (MPL) must take into account the maximum degree of damage it can cause, and the number of people exposed to risk (NP) lists the people who are exposed to danger.

In view of previous surveys we used the following equation (eq.1) to analyze the levels of risk:

$$
\text { Hazard Rating Number (HRN) = PE X FE X MPL X NP }
$$

To quantify the dangers cited, we can see the following tables where each one was used systematically for the verification of the risks. As Table 1 illustrates the occurrence of exposure to risk, that is, shows the person probability to access the danger zone for each existing risk in the machine. 
Table 1 - Probability for exposure (PE)

\begin{tabular}{l|l|l}
0 & Almost impossible & Can not happen on any \\
1 & Unlikely & Although conceivably \\
2 & Possible & But not current \\
5 & Any chance & It could happen \\
8 & Likely & Great chance of happening (unsurprisingly) \\
10 & Very likely & Expected \\
15 & Certain & Not doubt
\end{tabular}

Source: elaborated by the authors, 2017.

The Table 2, selects the frequency at which the person is exposed to evidenced danger.

\begin{tabular}{|c|c|}
\hline 0,1 & Rarely \\
\hline 0,2 & Anually \\
\hline 1 & Monthly \\
\hline 1,5 & Weekly \\
\hline 2,5 & Daily \\
\hline 4 & In terms of hours \\
\hline 5 & Constantly \\
\hline
\end{tabular}

Source: elaborated by the authors, 2017.

The maximum loss probability (MPL) can be exemplified in Table 3, which should choose the maximum loss that may occur as the danger that the person is exposed, that is, the maximum level of injury or damage to health.

Table 3 - Maximum probability of loss (MPL)
0,1
Scratch/mild concussion
0,5
Dilaceration/moderate disease
1
Fracture/ mild illness (temporary)
2
Fracture/ severe disease (permanent)
4
Loss of one body member/ eye or serious illness (temporary)
8
Loss of two body members/ eye or serious illness (permanent)
15
Fatality

Source: elaborated by the authors, 2017.

Table 4 indicates the number of exposed people at risk. 
Table 4 - Number of people exposed to risk (NP)

\begin{tabular}{l|l}
1 & $1-2$ people \\
2 & $3-7$ people \\
4 & $8-15$ people \\
8 & $16-50$ people
\end{tabular}

12

More than 50 people

Source: elaborated by the authors, 2017.

The ratings for each risk level is through the value obtained, presented in Table 5.

\begin{tabular}{|c|c|c|}
\hline Acceptable & $0-1$ & Aceptlable risk - consider possible actions \\
\hline Very low & $1-5$ & Up to 1 year \\
\hline Low & $5-10$ & Up to 3 months \\
\hline Significant & $10-50$ & Up to 1 month \\
\hline High & $50-100$ & Up to 1 week \\
\hline Towering & $100-500$ & Up to 1 day \\
\hline Extreme & $500-1000$ & Immediate action \\
\hline Unacceptable & $>1000$ & Stop activity \\
\hline
\end{tabular}

Source: elaborated by the authors, 2017.

According to Corrëa (2012) and tables 1-5, it can be seen that the risks can be classified into:

- Acceptable risk: just consider possible actions for improvements to the equipment;

- Very low risk: there is significant control measures required, but we recommend the use of personal protective equipment, and the implementation of training;

- Low risk: some control measures should be considered;

- Significant risk: additional control measures should be implemented to the system installed on the machine within a month;

- High risk: security control measures should be implemented within a week;

- Very high risk: security control measures should be implemented within a day;

- Extreme Risk: Security control measures should be implemented immediately; 
- Unacceptable risk: it must cease operation of work machine or equipment until the control measures have been adopted.

\section{Results and discussion}

Starting from the proposed goals, and implementation of the NR-12 in the pneumatic press tobacco, it was made a check of the existing dangers. From the description of the identified hazards, the causes and effects of the survey was conducted, seeking preventive or corrective measures regarding the gaps identified.

\subsection{Danger identification no. 01}

There is no physical protection that prevents operator access to the moving area (forward/reverse) in the car power. The lack of such protections in the moving area allows operator to put their upper members during forward/reverse car's power and may cause the loss.

RISK LEVEL $(H R N)=$ PE X FEX MPL XNP $=10 \times 4 \times 4 \times 1=160$

Rating: very high level of risk, should be provided the installation of protections within one day.

Given the results in Danger Identification No. 01, it is necessary to arrange the installation of physical protection, preventing members' access of the operator or personnel maintenance in the machine operation area, as shown in NR-12, in item 12.41. To protect the area, it is suggested to be used fixed protections with the protection grids type, which can be removed only with the use of appropriate tools.

Due to the danger to be located at a distance of up to $25 \mathrm{~mm}$ suggested by the norm, it is necessary the utilization of square grids with sizes ranging from $8 \mathrm{~mm}$ to $10 \mathrm{~mm}$ aperture, which allows only a finger of the worker be inserted into the danger zone. These protections shall be made of SAE1020 steel and must contain a metal frame provided with a central plate to increase the structural strength of the piece. Pillars between the grids must be installed to increase their strength.

With the implementation of security measures listed above probability of exposure (PE) is almost impossible, since the probability of maximum loss (MPL) is considered to be light scratch/contusion. In regard of this, it becomes classified as a level of acceptable risk where should be provided possible actions to improve safety. 


\subsection{Danger identification no. 02}

There is no physical protection that prevents operator access the charger moving area of the machine. The lack of protection when the charger performs its operation, up and down, can cause fracture and/or serious illness (permanent).

RISK LEVEL $(H R N)=$ PE X FE X MPL XNP $=10 \times 4 \times 2 \times 1=80$

Rating: high level of risk, and should be provided the installation of barriers within a week.

From the above result identified, there is a need to provide the installation of physical protection, preventing operator members' access in the operating area of the machine, as recommended by the NR-12 at its item 12.41 . We chose to use fixed protection, the grids protection types, to protect the area where they can be removed only with the use of appropriate tools.

As the danger is located at a distance of up to $5 \mathrm{~mm}$ as specifies norm, it is necessary to use perforated square plate with dimensions of $4 \mathrm{~mm}$ to $6 \mathrm{~mm}$ aperture, thereby allowing that only the tip of the finger be inserted into the danger zone. These protections shall be made of SAE-1020 steel and must contain a metal frame provided with a central plate to increase the structural strength of the piece. Note that this protection could be fixed directly to the machine frame.

With the implementation of security measures listed above the probability of exposure (PE) is improbable, since the probability of maximum loss (MPL) is considered light scratch/concussion. With this, it becomes classified as a level of acceptable risk, where should be provided possible actions to improve safety.

RISK LEVEL $($ HRN $)=1 \times 1 \times 0,1 \times 1=0,1$

\subsection{Danger identification no. 03}

In the pressing section, the danger description is characterized by lack of safety valve. The use of the safety valve is required so that in an emergency it can guarantee the immediate stop of the pneumatic circuit thus avoiding the loss of a member/eye or serious illness (temporary).

RISK LEVEL $(H R N)=$ PE X FE X MPL XNP $=5 \times 4 \times 4 \times 1=80$

Rating: high level of risk, and should be provided the installation of barriers within a week. 
It is suggested the use of safety valve category 04, as recommended in NR-12, in item 12.42 . For this valve be considered proper to security, needs to be cross-flow, double solenoid, manual reset and be certified.

However, it does not guarantee that a high load sustained by the cylinder upright go down when there is power failure or lack of air supply. Thus, it is suggested to install two more valves $3 / 2$ pneumatically piloted by another valve. We also suggest the use of two valves for the charger stop its motion in an emergency.

After implantation, the probability of exposure (PE) is classified as being in any chance, may occur light scratch and/or concussion. Thus, it becomes classified as a risk level too low, resulting in the installation of barriers over a period of up to one year.

$$
\text { RISK LEVEL }(H R N)=5 \times 4 \times 0,1 \times 1=2
$$

\subsection{Danger identification no. 04}

Lack of physical barriers on the sides of the cargo sector, as well as the need of installation of led barriers on the entrances and exits of the boxes. These barriers must be connected to sensors (muting system) that enable boxes only to access this area. The lack of this system allows people to enter into the danger zone of the machine that could cause a fatality.

$$
\text { RISK LEVEL }(H R N)=\text { PE X FE X MPL XNP }=10 \times 4 \times 15 \times 1=600
$$

Rating: extreme level of risk, where the action of improvements must be immediate.

As previously mentioned to protect the area it is suggested to use fixed rails protections, which could be evacuated only by the use of specific tools for this purpose, as the use of led barriers in the inputs and outputs of the boxes.

As the danger is located at a distance of up to $25 \mathrm{~mm}$ of the specified in the norm, the use of square grids with dimensions between $8 \mathrm{~mm}$ to $10 \mathrm{~mm}$ aperture, would allow only a finger of the worker to be inserted into the danger zone. These protections should be made of SAE-1020 steel and contain a metal frame consisting of a central lane thereby increasing the structural strength of the piece. Furthermore, this protection could be fixed directly to the machine frame.

The led barriers with a system known as muting allow only the boxes pass through the barrier preventing the operator to have access to the danger zone. Due to the cross-flow system, the system 
disables the barriers when a sequence is interrupted by the box. This system recognizes the material and can interpret the object and/or operator.

It is extremely important the installation of led barriers with muting system, as recommended in NR-12, in item 12.38. After taken the recommended safety measures, the probability of exposure to this danger becomes improbable, could occurring laceration/moderate disease, being an acceptable level of risk.

RISK LEVEL $(H R N)=1 \times 1,5 \times 0,5 \times 1=0,75$

\subsection{Danger identification no. 05}

Lack of handrails at the top of the press, with probability of exposure which may cause fracture and/or some serious illness (permanent) to operator's/maintenance personnel. Additionally, the lack of these handrails could cause the fall of the operator/maintenance personnel from the top of the machine.

RISK LEVEL $(H R N)=P E X F E X M P L X N P=10 \times 5 \times 2 \times 1=100$

Rating: high level of risk, and should be provided the installation of barriers within a week.

From this, it is necessary to install handrails on top and the ladder access, as indicated in NR-12, in item 12.68. To adapt the machine to lack of handrails, it is suggested the installation of round tubes with a diameter of $1 \frac{1}{2}$ "on the top, located in a surface of the floor of $1200 \mathrm{~mm}$. It was decided to round tube, as a function of the norm in its item 12.70 where it says that the cross bar should not have flat surfaces allowing to avoid the placement of objects. It is also necessary to install a bar with a diameter of $1 "$ at an intermediate height of $600 \mathrm{~mm}$ from the floor. Measures taken to the railings of the platform will also be used in ladder access.

The probability of exposure to this danger is still possible, and there may be risk of light scratch and/or concussion, featuring a level of acceptable risk, where it is possible to consider specific actions.

$$
\text { RISK LEVEL }(H R N)=2 \times 5 \times 0,1 \times 1=1
$$

\section{Conclusions}

Nowadays, the companies are seeking to minimize the dangerous to which their employees are exposed, thus ensuring the health, safety and physical integrity of their employees. Therefore, this study 
sought a proposal for deployment of Regulatory Norm 12 (NR-12) in tobacco pneumatic presses, suggesting also improvements to the factory

First, it was detected the need to implement NR-12 in tobacco pneumatic press. Weanalyzed the dangers involved, and consequently proposed improvements to them.

From this, we listed security measures that should be adopted for the implementation of the NR-12 in tobacco pneumatic press. It was evidenced that with the implementation of the security measures described in the development of this work, the machine is now in a safe condition for its operation, and for the operators. The work contributes to literature through the application in a limited, complex and specific machine. This is important due the low quantity of manufacturers for this type of equipment worldwide. As conclusion, our applied study allows a base for new case studies and comparisons in other contexts. The recommendation for future work would be a ratio assessment of the cost/benefit after the NR-12 process implementation in tobacco pneumatic presses.

\section{References}

Ajimotokan, H. A. (2012). Towards a rigorous equation-oriented technique for sustainable manufacturing safety programme. Journal of Manufacturing Technology Management, 23 (1), 76 86.

Anuário Brasileiro, (2010), available: <http://pt.scribd.com/doc/71315635/ANUARIO-BRASILEIROPROTECAO> (accessed May 18, 2012).

Areaseg, (2012), available: <http://www.areaseg.com/seg>. (accessed April 14, 2012).

Behzad, G. et al. (2007). Spare parts estimation and risk assessment conducted at Choghart Iron Ore Mine. Quality in Maintenance Engineering, 13 (4), 353-363.

Brasil, (2011). Ministério do Trabalho e Emprego. Norma Regulamentadora n 12. Segurança no trabalho em máquinas e equipamentos. Redação dada pela portaria $n^{\circ}$ 293/2011, available: <http://portal.mte.gov.br/legislacao/normas-regulamentadoras-1.htm> (accessed May 20, 2012).

Caputo, A.C. et al., (2013). AHP-based methodology for selecting safety devices of industrial machinery. Safety Science, 53, 202-218.

Cechin, J. \& Fernandes, A. Z. (2002). Ocorrência de Acidentes de Trabalho conforme a GFIP, available: <http://www.previdencia.gov.br/arquivos/office/3_081014-104507-784> (accessed May 18, 2012).

Chan, K. L. \& Chan, A. H. S. (2011). Understanding industrial safety signs: implications for occupational safety management. Industrial Management \& Data Systems, 111 (9), 1481-1510.

Ciesielski, J. V. R. (2013). Aplicação da NR-12 em prensas de pequeno porte para prensar blocos e tijolos ecológicos. 
Nara, E. O. B., Benitez, G. B., Silva, A. L. E., Hernandes, F., Kothe, J. V., Baierle, I. C., Schaefer, J. L., Vinha, F., Ellert, B., Schreiber, J. N. C., \& Furtado, J. C. (2021, abr./jun.). Implementation of regulatory standards for tobacco-Brazil presses

Cordeiro, R., Luz, V. G., Hennington, É. A., Martins, A. C. A., \& Tófoli, L. F. (2017). A violência urbana é a maior causa de acidente de trabalho fatal no Brasil. Revista de Saúde Pública, 51, 123-123.

Cordero, C. A. et al., (2009). Measurement of machinery safety level in the European market: A real case based on market surveillance data. Safety Science, 47, 1351-1358.

Corrëa, M. U., (2012). Sistematização e aplicações da NR-12 na segurança em máquinas e equipamentos, available: <http://bibliodigital.unijui.edu.br:8080/xmlui/handle/123456789/836> (accessed October 08, 2012).

Drakopoulos, S. et al. (2012). A survey of safety and health at work in Greece. International Journal of Workplace Health Management, 5 (1), 56-70.

Ferreira, M. J. M., Lima, R. K. S. D., Silva, A. M. C. D., Bezerra Filho, J. G., \& Cavalcanti, L. P. D. G. (2017). Surveillance of occupational accidents by sentinel workers' health

Fuller, C. W. \& Vassie, L. H. (2001). Benchmarking the safety climates of employees and contractors working within a partnership arrangement: a case study in the offshore oil industry. Benchmarking: An International Journal, 8(5), 413-430.

GONÇALVES FILHO, A. P., \& Ramos, M. F. (2015). Acidente de trabalho em sistemas de produção: abordagem e prevenção. Gest. Prod., São Carlos, 22(2), 431-442.

Junior, H. B. N. (2009). Os acidentes de trabalho em prensas analisados pelos Auditores Fiscais do Trabalho do Ministério do Trabalho e Emprego no período de 2001 a 2006, available: <http://www.athena.biblioteca.unesp.br/exlibris/bd/bbo/33004064078P9/2009/nobrejunior_hb_m e_botfm.pdf> (accessed May 18, 2012).

Kuo-Chung Shang, K. C. (2011). The effect of safety management on perceived safety performance in container stevedoring operations. Shipping and Transport Logistics, 3 (3).

Ministry of Social Security, (2019), available: <http://www3.dataprev.gov.br/temp/DACT01consulta43977927.htm> (accessed April 11, 2019).

Macedo, D. X. S., Monteiro, L. D. A., Santos, V. C. D., Albiero, D., \& Chioderoli, C. A. (2015).Characterization of accidents with farm machinery on federal highways in the state of Rio Grande do Sul, Brazil. Ciência Rural, 45(1), 43-46.

Machado, J. M., \& Gomez, C. M. (1994). Acidentes de trabalho: uma expressão da violência social. Cadernos de Saúde Pública, 10, S74-S87.

Pacheco Jr.,W. (1995), Qualidade na Segurança e Higiene do Trabalho. Série SHT 9000, Normas para a Gestão e Garantia da Segurança e Higiene do Trabalho. São Paulo: Atlas.

Pinto, A. K \& Xavier, J. A. N. (2001). Manutenção: Função Estratégica. Rio de Janeiro: Qualitymarck Ed.

Prochnow, A., de Souza Magnago, T. S. B., Tavares, J. P., Beck, C. L. C., da Silva, R. M., da Silva Ceron, M. D., \& de Castro, R. R. (2012). Acidente de trabalho: uma revisão

Raouf, A. (2004). Productivity enhancement using safety and maintenance integration. Kybernetes, 33 (7), 1116-1126. 
Riis, J. O. et al. (2007). Strategic roles of manufacturing. Journal of Manufacturing Technology Management, 18 (8), 933-948.

Ruz, M. L. et al. (2012). Robotic testing of radio frequency devices designed for industrial safet. Safety Science, 50, 1606-1617.

Salaheldin, S. I. \& Zain, M. (2007). How quality control circles enhance work safety: a case study. The TQM Magazine, 19 (3), 229-244.

Savi, G. (2012). Redução de acidentes: um objetivo a ser alcançado, available: <http://blog.mte.gov.br/?p=5375>. (accessed May 18, 2012).

Silva, I. B. R. \& Souza, B. S. (2011). Proteção de Máquinas: A Melhor Alternativa. Revista Proteção, 239, 76-81.

Vasconcelos, F. M. D. et al. (2015). Hazards at workplace in the baking sector: a case study in two cookie industries. Gestão \& Produção, 22(3), 565-589.

Veiga, J. P. C., Trevisani, D. M., Makishi, F., Abreu, M. G. C. D., Silva, M. S. P., \& Zacareli, M. A. (2017). Health and safety standards in labor and extractivism: the case of rural communities in Brazilian Amazon. Saúde e Sociedade, 26(3), 774-785.

Veiga, R. K., Gontijo, L. A., Masiero, F. C., Maas, L., \& Odorizzi, W. (2017). Accidents with power tillers used for onion cultivation in Santa Catarina State, Brazil. Horticultura Brasileira, 35(1), 124-128. 